\title{
Effect of Nano-Fertilizer (Lithovit) and Potassium on Leaves Chemical Composition of Egyptian Cotton Under Different Planting Dates. Attia, A. N. E. ${ }^{1}$; M. H. El-Hendi ${ }^{1}$; S. A. F. Hamoda ${ }^{2}$ and Shiamaa O. S. El-Sayed ${ }^{2}$ \\ ${ }^{1 \cdot A g r o n o m y ~ D e p a r t m e n t, ~ F a c u l t y ~ o f ~ A g r i c u l t u r e, ~ M a n s o u r a ~ U n i v e r s i t y, ~ E g y p t . ~}$ \\ ${ }^{2-}$ Cotton Research Institute, Agriculture Research Center, Giza, Egypt.
}

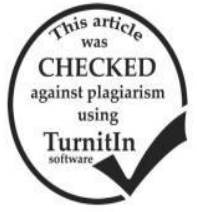

\section{ABSTRACT}

Two field experiments were carried out at El-Gemmeiza Agricultural Research Station, El-Gharbia Governorate in 2014 and 2015 seasons, to study the effect of nano-fertilizer (Lithovit) rates $(0,2.5,5$ and $7.5 \mathrm{~g} / \mathrm{l})$ and foliar potassium fertilizer (in the form of Potasin-P) rates $\left(2.5,5\right.$ and $\left.7.5 \mathrm{~cm}^{3} / \mathrm{l}\right)$ under three planting dates (8 April, 8 May and 8 June) on leaves chemical composition of the Egyptian cotton (Gossypium barbadense L.), cultivar Giza 86. Cotton plants were foliar sprayed with Lithovit and Potasin-P at 45 and 60; 46 and 61 days after planting, respectively. Leaves N, P, K, chlorophyll a, b, total chlorophyll, carotenoids and total carbohydrates contents were significantly affected by planting date in both seasons, in favour of early planting date ( 8 April) compared to medium and late planting dates ( 8 May and 8 June). Delaying planting date significantly increased leaf proline content and leaf peroxidase activity which indicate the presence of heat stress effect on the plant.Leaves $\mathrm{N}$, chlorophyll a, b, total chlorophyll, carotenoids and total carbohydrates contents were significantly affected by rates of Potasin-P in both seasons, in favour of the medium rate of Potasin- $\mathrm{P}\left(5 \mathrm{~cm}^{3} / \mathrm{l}\right)$. While, leaves $\mathrm{P}$ and $\mathrm{K}$ contents were significantly increased by using the high rate of Potasin-P $\left(7.5 \mathrm{~cm}^{3} / 1\right)$. The medium rate of Potasin-P $\left(5 \mathrm{~cm}^{3} / 1\right)$ significantly decreased leaf proline content and peroxidase activity which indicate favorable plant conditions.Leaves $\mathrm{N}, \mathrm{P}, \mathrm{K}$, chlorophyll a, b, total chlorophyll, carotenoids and total carbohydrates contents were significantly increased by each increment of nano-fertilizer (Lithovit). The inverse was true in leaf proline content and peroxidase activity. The decrease in these traits induced favorable plant conditions and reflected on reduce environmental stress effect.The second order interaction had a significant effect on all studied chemical composition of leaves. Cotton plants sown on 8 April and sprayed with $5 \mathrm{~cm}^{3}$ Potasin-P $/ 1$ and $7.5 \mathrm{~g}$ Lithovit/l recorded the highest values of $\mathrm{N}, \mathrm{P}, \mathrm{K}$, chlorophyll a, b, total chlorophyll, carotenoids and total carbohydrates content in leaves. In the contrary, this interaction recorded the lowest values of leaf proline content and peroxidase activity which induced favorable plant conditions and reflect on reduce environmental stress effect. It can be concluded that the mentioned interaction was the recommended treatment for optimum chemical composition of cotton leaves under experimental conditions.

\section{INTRODUCTION}

Cotton (Gossypium spp.) is highly sensitive to environmental stresses. Singh et al. (2007) reported that in the last century, carbon dioxide concentration $\left[\mathrm{CO}_{2}\right]$ has risen rapidly from about $350 \mathrm{mmol} \mathrm{mol}^{-1}$ in 1980 to about $378 \mathrm{mmol} \mathrm{mol}^{-1}$ at present. At the current rate of gas emissions and population increase, it is predicted that $\mathrm{CO}_{2}$ will double by end of this century. These changes in $\mathrm{CO}_{2}$ and other greenhouse gases are predicted to increase surface mean temperature in the range of $1.4-5.8{ }^{\circ} \mathrm{C}$. In this concern, Oosterhuis (1999) reported that the overall result of high temperature was insufficient carbohydrates production to satisfy the plant's needs. Reddy et al. (1995) observed that net photosynthesis in cotton was less at both higher and lower temperatures than at optimum $\left(28{ }^{0} \mathrm{C}\right)$. Net photosynthesis decreases with increasing temperature, while dark respiration increases exponentially with increasing temperatures (Bednarz and Van Iersal, 2001). High temperature increases rates of photorespiration (Krieg, 1986), thus reduces net carbon gain in $\mathrm{C}_{3}$ species. Al-Khatib and Paulsen (1984) and Harding et al. (1990) detected differences in photosynthesis under heat stress that were associated with a loss of chlorophyll and changes in the ratio of chlorophyll a to b. El- Shazly et al. (1998) found that early planting date (March 15) significantly increased leaf concentrations of $\mathrm{N}, \mathrm{P}$ and $\mathrm{K}$ in both seasons as compared to mid and late sowing dates (April 5 and April 26). Ali (2012) found that the total soluble carbohydrates in the stem of cotton seedling was reached significantly to planting date in favor of early sowing. El - Ashmouny (2014) found that planting cotton at 15 April give the highest values in leaf chlorophyll a, chlorophyll b, total chlorophyll and carotenoids content compared to the other planting dates (30 April or 15 May).

Although fertilizers are very important for plant growth and development, most of the applied fertilizers are rendered unavailable to plants due to many factors, such as leaching, degradation by photolysis, hydrolysis and decomposition. Hence, it is necessary to minimize nutrient losses in fertilization and to increase the crop yield through the exploitation for new applications with the help of nanotechnology and nanomaterials. Nanotechnology opens a large scope of novel application in the fields of biotechnology and agricultural industries, because nanoparticles have unique physicochemical properties, i.e. high surface area, high reactivity, tunable pore size and particle morphology (Siddiqui et al., 2015). Kumar (2011) reported that nano fertilizers have emerged as an alternative to conventional fertilizers for slow release and efficient use of water and fertilizers by plants. These prevent buildup of the nutrients in the soil thereby eliminating the risk of eutrophication and drinking water contamination. Lithovit is a naturally occurring $\mathrm{CO}_{2}$ foliar spray made from limestone deposits. It enhances the plant growth and results in high productivity by means of increasing the natural photosynthesis on supplying carbon dioxide $\left(\mathrm{CO}_{2}\right)$ at optimum concentration, which is much higher than in the atmosphere and at the same time does not result in an increase of the $\mathrm{CO}_{2}$ in the atmosphere which might create a climatic problem particularly when the rate of global warming looms large over agriculture. All Lithovit particles do not penetrate the stomata at once. Most of them remain as thin layer on the leaves surface 
and penetrate frequently when they get wet by dew at night.

Foliar feeding of potassium is of great significance for plants because its includes low cost, quick response to plant, small quantity of potassium and it provides compensation for lack of soil fixation (Ashfaq et al., 2015). Cakmak et al. (1994) reported that $\mathrm{K}$ nutrition pronounced effect on carbohydrates partitioning by affecting either phloem export of photosynthesis (sucrose) or growth rate of sink /or sucrose's organ. Dong et al. (2004) reported that potassium deficiency is closely associated with low chlorophyll content, decreased stomatal conductance, poor chloroplast and increased mesophyll resistance. Reddy and Zhao (2005) found a significant difference in leaf chlorophyll content among $\mathrm{K}$ treatments (control and $40,20,5$ and $0 \%$ of the control $\mathrm{K}$ ).

The objective of this study was to determine the interactive effects of potassium fertilizer (in the form of Potasin-P) supply at the three rates and nano-fertilizer (Lithovit) at the four rates on cotton leaves chemical composition under three planting dates under the environmental conditions of El-Gharbia Governorate.

\section{MATERIALS AND METHODES}

Two field experiments were conducted on a clay soil at El-Gemmeiza Agricultural Research Station, ElGharbia Governorate, Egypt in 2014 and 2015 seasons, to study the effect of nano-fertilizer (Lithovit) rates (0, $2.5,5$ and $7.5 \mathrm{~g} / \mathrm{l})$ and foliar Potasin-P rates (2.5, 5 and $7.5 \mathrm{~cm}^{3} / \mathrm{l}$ ) under three planting dates (8 April, 8 May and 8 June) on leaves chemical composition of the Egyptian cotton, cultivar Giza 86.

The preceding crop was Egyptian clover (Trifolium alexandrinum L.,) "berseem" in both seasons.

Representative soil samples were taken from the experimental soil sites before sowing in both seasons and prepared for analysis to determine chemical properties according to Jackson (1973) as shown in Table (1).

Table. 1. Chemical properties of the experimental soil sites in the two seasons.

\begin{tabular}{|c|c|c|c|}
\hline Properties & $\begin{array}{l}\text { Season } \\
2014 \quad 2015\end{array}$ & Properties & $\begin{array}{c}\text { Season } \\
20142015\end{array}$ \\
\hline$\overline{\mathrm{pH}}$ & 8.17 .8 & CationsMeq/1 & \\
\hline EC mmhos $/ \mathrm{cm}$. & 0.230 .26 & $\mathrm{Ca}^{++}$ & 1.171 .33 \\
\hline Organic matter $\%$ & 1.591 .29 & $\mathrm{Mg}^{++}$ & $\begin{array}{ll}0.7 & 0.84\end{array}$ \\
\hline Total N (mg/100g) & $55.65 \vdash 5.15$ & $\mathrm{Na}^{+}$ & 3.183 .40 \\
\hline Available N (ppm) & 28.121 .3 & $\mathrm{~K}^{+}$ & 0.140 .10 \\
\hline Available P (ppm) & 11.810 .7 & Anions & \\
\hline Exchangeable K (ppm) & $354 \quad 312$ & Meq/1 & \\
\hline Available $\mathrm{Fe}$ (ppm) & 11.810 .6 & $\mathrm{CO}_{3}^{--}$ & - \\
\hline Available Mn (ppm) & 3.13 .8 & $\mathrm{HCO}_{3}^{-}$ & 0.870 .90 \\
\hline Available Zn (ppm) & 1.31 .1 & $\mathrm{Cl}^{-}$ & 2.222 .41 \\
\hline Available $\mathrm{Cu}(\mathrm{ppm})$ & $3.5 \quad 3.22$ & $\mathrm{SO}_{4}^{-}$ & 2.102 .36 \\
\hline
\end{tabular}

The different constituents of Lithovit were illustrated in Table 2.

Table 2 . Main characteristics of Lithovit used in the study

\begin{tabular}{|c|c|c|c|}
\hline Component (\%) & Value & $\begin{array}{c}\text { Component } \\
(\%)\end{array}$ & Value \\
\hline $\begin{array}{l}\text { Calcium } \\
\text { carbonate }\end{array}$ & 79.19 & Sulphate & 0.33 \\
\hline Nitrogen & 0.06 & Iron & 1.31 \\
\hline Phosphate & 0.01 & Zinc & 0.005 \\
\hline Potassium oxide & 0.21 & Manganese & 0.014 \\
\hline $\begin{array}{l}\text { Magnesium } \\
\text { carbonate }\end{array}$ & 4.62 & Copper & 0.002 \\
\hline Selisium dioxide & 11.41 & Clay & 0.79 \\
\hline
\end{tabular}

A strip split plot design with four replicates was used in both seasons. The horizontal plots were assigned to planting dates, the vertical plots to Potasin$P$ rates and sub-plots to nano-fertilizer (Lithovit) rates. The plot size was $14 \mathrm{~m}^{2}(4 \mathrm{~m} \times 3.5 \mathrm{~m})$. Each plot included 5 ridges $70 \mathrm{~cm}$ apart. Phosphorus fertilizer was applied during soil preparation in the form of calcium super phosphate $\left(15.5 \% \mathrm{P}_{2} \mathrm{O}_{5}\right)$ at a rate of 22.5 $\mathrm{kg} \mathrm{P}_{2} \mathrm{O}_{5} /$ fed. Sowing took place on the studied dates. Seeds of Giza 86 cultivar were sown in hills $25 \mathrm{~cm}$ apart with two plants /hill after thinning. All plots were fertilized at a rate of $45 \mathrm{~kg} \mathrm{~N} /$ fed in the form of ammonium nitrate $(33.5 \% \mathrm{~N})$ in two equal doses, the first dose was added after thinning (before the first irrigation), while the second dose was applied before the second irrigation. Potassium fertilizer (in the form of Potasin-P) was applied as foliar spray at the tested rates.

Solutions of Potasin-P $\left(30 \% \mathrm{~K}_{2} \mathrm{O}+5 \% \mathrm{P}_{2} \mathrm{O}_{5}\right)$ and Lithovit with the mentioned concentrations were used as foliar spray on cotton plants twice at 46 and $61 ; 45$ and 60 days after planting, respectively.

The other cultural practices were carried out as recommended for conventional cotton seeding in the local production district.

Ten leaves (fourth upper leaf) were randomly taken from plants of each plot at 75 days after sowing to determine mineral elements, photosynthetic pigments and total carbohydrates in both seasons and proline concentration and determination of enzyme activity in the first season, only. $\mathrm{N}$ was determined in leaves by microkjeldahl, $\mathrm{P}$ by spectrometer, $\mathrm{K}$ by flame photometer, photosynthetic pigments (chlorophyll a, chlorophyll $\mathrm{b}$, total chlorophyll $(\mathrm{a}+\mathrm{b})$ and carotenoids) by spectrophotometer model 390 and total carbohydrates by spectro-colorimetrically as described by A.O.A.C. (1995). Proline concentration was measured by colorimeter according to the method of Bates et al. (1973) and peroxidase activity was determined according to the method of Fehrman and Dimond (1967).

Statistical analysis

The statistical analysis of the obtained data was done and performed according to Le Clerg et al. (1966) using M State-C microcomputer program for strip split plot design, and the treatments means were compared 
using LSD at 0.05 level of probability (Waller and Duncan, 1969).

\section{RESULTS AND DISCUSSION}

\section{1-Effect of planting dates:}

Planting dates had significant effect on leaf N, K, chlorophyll a, b, a+b, carotenoids and total carbohydrates content at 75 days from planting in both seasons (Tables 3, 4 and 5). Early planting date (8 April) resulted in significant increase in these traits as compared to mid and late planting dates (May 8 and June 8). In contrary, late planting date recorded the lowest values of these traits. This could be explained on the basis of air temperature and heat units, where in delaying planting date accumulated temperatures degrees above the zero point of growth were increased and consequently respiration increase and in turn leaf total carbohydrates content decreased. In this concern, Perry and Krieg (1981) reported that temperatures exceeding $32^{\circ} \mathrm{C}$ are associated with a decrease in photosynthesis and carbohydrates production. Burke et al. (1988) reported that the temperature ranges of cotton for optimal metabolic activity, known as the thermal kinetic window, is $23-32{ }^{\circ} \mathrm{C}$ with the optimum for photosynthesis at $28^{\circ} \mathrm{C}$. Al- Khatib and Paulsen (1984) and Harding et al. (1990) detected similar differences in photosynthesis under heat stress that were associated with a loss of chlorophyll and changes in the ratio of chlorophyll a to b. El-Shazly et al. (1998) found that early planting date (March 15) significantly increased leaf concentration of $\mathrm{N}, \mathrm{P}$ and $\mathrm{K}$ in both seasons as compared to mid and late sowing dates (April 5 and April 26). Ali (2012) reported that average total soluble carbohydrates tended to be decreased drastically as planting date was delayed. El - Ashmouny (2014) found that planting cotton at 15 April give the highest values in leaf chlorophyll a, chlorophyll b, total chlorophyll and carotenoids content compared to the other planting dates (30 April or 15 May).

Delaying planting date significantly increased leaf proline concentration and peroxidase activity (Table 5), which indicated unfavorable plant conditions and this reflect on increase environmental stress effect. In this concern, Ronde et al., (2001) found that proline accumulation in high temperature in cotton leaves. Peroxidase is antioxidant enzyme that is very good biochemical marker for stress and increasing its activity could have a remediation potential (Zembala et al., 2010).

\section{2-Effect of Potasin-P rates:}

Significant differences among the three rates of Potasin-P for leaves N, P, K, chlorophyll a, b, a+b, carotenoids and total carbohydrates content at 75 days from planting in both seasons were found, in favor of foliar spraying the medium rate of Potasin-P $\left(5 \mathrm{~cm}^{3} / \mathrm{l}\right)$ for leaves N, chlorophyll a, b, a+b, carotenoids and total carbohydrates content in both seasons and in favor of the high rate $\left(7.5 \mathrm{~cm}^{3} / 1\right)$ for leaves $\mathrm{P}$ and $\mathrm{K}$ contents in both seasons. The significant increase in leaves $\mathrm{P}$ and $\mathrm{K}$ content due to applied Potasin-P at the high rate (7.5 $\mathrm{cm}^{3} / \mathrm{l}$ ) over the other two rates is mainly due to the constituents of Potasin-P $\left(30 \% \mathrm{~K}_{2} \mathrm{O}\right.$ and $\left.5 \% \mathrm{P}_{2} \mathrm{O}_{5}\right)$. In contrary, the medium rate produced the lowest values of leaves proline concentration and peroxidase activity, which indicated that this rate induced favorable plant conditions and this reflect on reduce environmental stress effect. In this concern, Cakmak et al. (1994) reported that $\mathrm{K}$ nutrition pronounced effect on carbohydrates partitioning by affecting either phloem export of photosynthesis (sucrose) or growth rate of sink /or sucrose's organ. In addition, $\mathrm{K}$ has an important role in the translocation of photosynthates from sources to sinks. Zhao et al. (2001) reported that the $\mathrm{K}$ deficient plant leaves were filled with more starch granules and fewer grana as compared to $\mathrm{K}$ sufficient plants. Dong et al. (2004) reported that potassium deficiency is closely associated with low chlorophyll content, decreased stomatal conductance, poor chloroplast and increased mesophyll resistance and Reddy and Zhao (2005) reported that plants receiving 5 and $0 \% \mathrm{~K}$ had 12 and $38 \%$ lower chlorophyll content than the control, respectively.

Table. 3. Effect of planting date, Potasin-P rate and Lithovit rate as well as their interactions on leaves nitrogen, phosphorus and potassium contents $(\%)$ in 2014 and 2015 seasons.

\begin{tabular}{|c|c|c|c|c|c|c|}
\hline \multirow[b]{2}{*}{ Treatments } & \multicolumn{2}{|c|}{$\mathbf{N}(\%)$} & \multicolumn{2}{|c|}{$\mathbf{P}(\%)$} & \multicolumn{2}{|c|}{$\mathbf{K}(\%)$} \\
\hline & $\begin{array}{c}2014 \\
\text { season }\end{array}$ & $\begin{array}{c}2015 \\
\text { season }\end{array}$ & $\begin{array}{c}2014 \\
\text { season }\end{array}$ & $\begin{array}{c}2015 \\
\text { season }\end{array}$ & $\begin{array}{c}2014 \\
\text { season }\end{array}$ & $\begin{array}{c}2015 \\
\text { season }\end{array}$ \\
\hline \multicolumn{7}{|c|}{ A-planting date } \\
\hline 8 April & 3.42 & 3.45 & 0.51 & 0.54 & 3.47 & 3.62 \\
\hline 8 May & 3.37 & 3.39 & 0.45 & 0.47 & 3.33 & 3.57 \\
\hline 8 June & 3.24 & 3.26 & 0.33 & 0.33 & 3.21 & 3.26 \\
\hline LSD 0.05 & 0.02 & 0.01 & 0.01 & 0.02 & 0.03 & 0.01 \\
\hline \multicolumn{7}{|l|}{$\begin{array}{l}B \text {-Potasin-P } \\
\text { rate }\end{array}$} \\
\hline $2.5 \mathrm{~cm}^{3} / 1$ & 3.33 & 3.35 & 0.42 & 0.43 & 3.31 & 3.43 \\
\hline $5.0 \mathrm{~cm}^{3} / 1$ & 3.37 & 3.40 & 0.43 & 0.45 & 3.35 & 3.49 \\
\hline $7.5 \mathrm{~cm}^{3} / 1$ & 3.33 & 3.35 & 0.45 & 0.46 & 3.36 & 3.53 \\
\hline LSD 0.05 & 0.01 & 0.01 & 0.01 & 0.01 & 0.01 & 0.01 \\
\hline \multicolumn{7}{|l|}{ C-Lithovit rate } \\
\hline without & 3.27 & 3.28 & 0.37 & 0.39 & 3.27 & 3.41 \\
\hline $2.5 \mathrm{~g} / 1$ & 3.33 & 3.35 & 0.41 & 0.43 & 3.31 & 3.45 \\
\hline $5.0 \mathrm{~g} / \mathrm{l}$ & 3.36 & 3.39 & 0.45 & 0.47 & 3.36 & 3.50 \\
\hline $7.5 \mathrm{~g} / 1$ & 3.41 & 3.44 & 0.48 & 0.49 & 3.41 & 3.56 \\
\hline LSD 0.05 & 0.02 & 0.01 & 0.01 & 0.01 & 0.01 & 0.01 \\
\hline \multicolumn{7}{|l|}{ Interactions } \\
\hline$A \times B$ & NS & $* *$ & NS & NS & $* *$ & NS \\
\hline $\mathrm{A} \times \mathrm{C}$ & $* *$ & $* *$ & $* *$ & $* *$ & $* *$ & $* *$ \\
\hline B X C & $*$ & NS & NS & $* *$ & $*$ & $* *$ \\
\hline $\mathrm{A} \times \mathrm{B} \times \mathrm{C}$ & $*$ & $* *$ & $*$ & $* *$ & $* *$ & $* *$ \\
\hline
\end{tabular}

3-Effect of nano- fertilizer (Lithovit) rates:

Leaves N, P, K, chlorophyll a, b, total chlorophyll, carotenoids and total carbohydrates concentrations were significantly increased by each increment of nano-fertilizer (Lithovit). The inverse was true in leaf proline content and peroxidase activity. The decrease in these traits induced favorable plant conditions and reflected on reduce environmental stress effect.

The increase in leaves chlorophyll $a, b$ and $a+b$ content due to the high rate of nano-fertilizer (Lithovit) is mainly attributed with the high leaves $\mathrm{N}$ content of 
this rate (Table 3), which is an integral part of chlorophyll manufacture through photosynthesis (Tucker, 1999). The positive response of cotton plants to nano - fertilizer (Lithovit) as a foliar spray at the high rate compared with unfertilized plants or the low rate is mainly due to Lithovit contents of macronutrients (N, P, $\mathrm{K}, \mathrm{Ca}$ and $\mathrm{Mg}$ ) and micronutrients ( $\mathrm{Fe}, \mathrm{Zn}, \mathrm{Mn}$ and $\mathrm{Cu}$ ) as shown in Table (2) where:

Phosphorus is essential for the biosynthesis of chlorophyll as pyridoxal must be present for its biosynthesis. Phosphorus is involved in phosphoglecric compounds and phosphoglycric acid which plays an important role in $\mathrm{CO}_{2}$ conversion to sugar (Uchida, 2000). Magnesium ( $\mathrm{Mg}$ ) is a constituent of the chlorophyll molecule, which is the driving force of photosynthesis (Tucker, 1999). Zinc is essential for several biochemical processes such as cytochrome and nucleotide synthesis, auxin metabolism, chlorophyll production, enzyme activation and membrane integrity (Uchida, 2000).

Table. 4. Effect of planting date, Potasin-P rate and Lithovit rate as well as their interactions on leaves chlorophyll a, chlorophyll $b$ and total chlorophyll contents in 2014 and 2015 seasons.

\begin{tabular}{ccccccc}
\hline & \multicolumn{2}{c}{ Chlorophyll a } & \multicolumn{2}{c}{ Chlorophyll b } & \multicolumn{2}{c}{ Total chlorophyll } \\
Treatments & $(\mathrm{mg} / \mathrm{g}$ dwt) & \multicolumn{2}{c}{$(\mathrm{mg} / \mathrm{g}$ dwt $)$} & \multicolumn{2}{c}{$(\mathrm{mg} / \mathrm{g}$ dwt } \\
& $\mathbf{2 0 1 4}$ & 2015 & 2014 & 2015 & 2014 & 2015 \\
& season & season & season & season & season & season \\
\hline
\end{tabular}

\begin{tabular}{lcccccc} 
& season & season & season & season & season & season \\
\hline $\begin{array}{l}\text { A-planting } \\
\text { date }\end{array}$ & & & & & & \\
$\quad$ 8 April & 3.66 & 3.99 & 1.69 & 1.76 & 5.35 & 5.75 \\
$\quad$ 8 May & 3.47 & 3.65 & 1.50 & 1.72 & 4.98 & 5.37 \\
$\quad$ 8 June & 3.20 & 3.43 & 1.45 & 1.67 & 4.65 & 5.09 \\
LSD 0.05 & 0.02 & 0.01 & 0.04 & 0.01 & 0.07 & 0.03 \\
$\begin{array}{l}\text { B-Potasin-P } \\
\text { rate }\end{array}$ & & & & & & \\
$2.5 \mathrm{~cm}^{3} / 1$ & 3.36 & 3.42 & 1.36 & 1.42 & 4.72 & 4.84 \\
$5.0 \mathrm{~cm}^{3} / 1$ & 3.63 & 3.87 & 1.93 & 2.06 & 5.56 & 5.93 \\
$7.5 \mathrm{~cm}^{3} / 1$ & 3.34 & 3.78 & 1.36 & 1.67 & 4.70 & 5.44 \\
LSD 0.05 & 0.04 & 0.01 & 0.07 & 0.01 & 0.10 & 0.04 \\
C-Lithovit rate & & & & & & \\
without & 3.26 & 3.52 & 1.44 & 1.59 & 4.70 & 5.11 \\
$2.5 \mathrm{~g} / 1$ & 3.35 & 3.60 & 1.52 & 1.67 & 4.87 & 5.27 \\
$5.0 \mathrm{~g} / 1$ & 3.51 & 3.76 & 1.57 & 1.76 & 5.08 & 5.52 \\
$7.5 \mathrm{~g} / 1$ & 3.65 & 3.88 & 1.65 & 1.89 & 5.30 & 5.72 \\
LSD 0.05 & 0.02 & 0.02 & 0.02 & 0.01 & 0.04 & 0.03 \\
Interactions & & & & & & \\
A x B & $* *$ & $* *$ & $* *$ & $* *$ & $* *$ & $* *$ \\
A X C & $* *$ & $* *$ & $* *$ & $* *$ & $* *$ & $* *$ \\
B X C & $* *$ & $* *$ & $* *$ & $* *$ & $* *$ & $* *$ \\
A X B X C & $* *$ & $* *$ & $* *$ & $* *$ & $* *$ & $* *$ \\
\hline
\end{tabular}

Zinc encourages green plastids enzymes and delays the senescence of plant through increasing levels of indole acetic acid (IAA) and chlorophyll. Zinc is necessary for chlorophyll synthesis and ATP/chlorophyll ratio. Although $\mathrm{Mn}$ is not a constituent of chlorophyll, it helps in its formation where, manganese assists iron in chlorophyll formation (Lohry, 2007). $\mathrm{Cu}$ is part of the chloroplast protein plastocyanin, which forms part of the electron transport chain. Also, $\mathrm{Cu}$ may have a role in the synthesis and/or stability of chlorophyll and other plant pigments (Uchida, 2000). Because $\mathrm{Cu}$ is essential for chloroplast functions, deficiency normally promotes chlorosis in young growth. Consequently, $\mathrm{Cu}$ deficiency is most likely to be observed in high pH soils (Hull, 2002), sulfur is necessary in chlorophyll formation (though it isn't one of the constituents), Tucker (1999). Iron promotes formation of chlorophyll. Iron is required for various reaction steps in the biosynthesis of chlorophyll, where iron plays a role in the formation of amino leulinic acid, which is a precursor of chlorophyll synthesis. It is essential for the synthesis of chlorophyll, the green color of plants which functions in photosynthesis but it is not part of the chlorophyll molecule, Curie and Briat (2003). In this concern, Pinter et al. (1994) found that cotton leaves in a free-air $\mathrm{CO}_{2}$ enrichment $\left(550 \mu \mathrm{mol} \mathrm{CO} \mathrm{Col}^{-1}\right)$ plots had greater chlorophyll a concentration than leaves in the ambient air control plots (about $370 \mu \mathrm{mol} \mathrm{CO} \mathrm{mol}^{-1}$ ). Reddy and Zhao (2005) found that leaf chlorophyll content did not differ $(\mathrm{P}=0.4)$ between plants grown under elevated and ambient $\left[\mathrm{CO}_{2}\right]$. Dordas (2009) found that manganese application increased the chlorophyll content.

The superiority of the high rate as for leaves carbohydrates content on the other rates is mainly refers to the characteristics of Lithovit and its chemical composition, where:

Potassium has an important role in the translocation of photosynthates from sources to sinks (Cakmak et al., 1994). Calcium aids in carbohydrates translocation (Tucker, 1999). Magnesium (Mg) is a constituent of the chlorophyll molecule, which is the driving force of photosynthesis. It is also essential for metabolism of carbohydrates (sugars). It facilitates the translocation of carbohydrates (sugars and starches) (Tucker, 1999). Phosphorus decomposes carbohydrates produced in photosynthesis (Tucker, 1999). Phosphorus is involved in phosphoglecric compounds and phosphoglycric acid which plays an important role in $\mathrm{CO}_{2}$ conversion to sugar (Uchida, 2000), Since $\mathrm{Cu}$ is required for the photosynthesis generation of reducing power necessary for $\mathrm{CO}_{2}$ fixation, an inadequate $\mathrm{Cu}$ supply will reduce carbohydrates level and vegetative growth rates. Photosynthesis involves the reduction of carbon dioxide $\left(\mathrm{CO}_{2}\right)$ while respiration is the oxidation of carbohydrates back to $\mathrm{CO}_{2}, \mathrm{Cu}$ is an essential participant in this process (Tucker, 1999). Ainsworth (2008) reported that due to increased photosynthetic activity, leaf nonstructural carbohydrates (sugars and starches) per unit leaf area increase on average by 30$40 \%$ under a free-air $\mathrm{CO}_{2}$ enrichment (FACE) elevated $\mathrm{CO}_{2}$.

Increasing Lithovit rate up to $7.5 \mathrm{~g} / \mathrm{l}$ caused a significant decrease in leaves proline content and leaf peroxidase activity due to the following considerations:

Lithovit improves the supply of essential nutrients such as manganese, copper, zinc, calcium, iron, potassium oxide, nitrogen and phosphorus etc that enhance the resistance to adverse conditions. Lithovit fed cotton plant leaves with $\mathrm{CO}_{2}$ gas from inside the leaves at a much higher rate than in the air, thus enhancing the basic process of photosynthesis and plant growth which reflects on provide the best conditions for plant growth. The high leaf nitrogen content due to this rate (Table 3) makes these plants utilized of the 


\section{J. Plant Production, Mansoura Univ., Vol. 7 (9), September, 2016}

absorbed light energy in electron transport and tolerant to photo-oxidative damage under high intensity light and consequently increases photosynthesis capacity. Calcium is able to mitigate heat stress effects by improving stomatal function and other cell processes. Calcium is also believed to have an influence on the development of heat shock proteins that help the plant tolerance the stress of prolonged heat. Insufficient $\mathrm{Ca}$ levels lead to deterioration of the cell membrane the cells become leaky resulting in the loss of cell compounds and eventually death of the cell and plant tissue. Calcium plays a role in regulating various cell and plant functions as a secondary messenger. This function as a secondary messenger assists in various plant functions from nutrient uptake to changes in cell status to help the plant react to the impact of environmental and diseases stresses

Table. 5. Effect of planting date, Potasin-P rate and Lithovit rate as well as their interactions on leaves carotenoids and total carbohydrates content (mg/g dwt) in 2014 and 2015 seasons and leaves proline concentration and leaves peroxidase activity in 2014 season.

\begin{tabular}{|c|c|c|c|c|c|c|}
\hline \multirow[b]{2}{*}{ Treatments } & \multicolumn{2}{|c|}{ Carotenoids (mg/g dwt) } & \multicolumn{2}{|c|}{ Total carbohydrates (mg/g dwt) } & \multicolumn{2}{|c|}{2014 season } \\
\hline & 2014 season & 2015 season & 2014 season & 2015 season & $\begin{array}{c}\text { Proline }(\mu \mathrm{g} \\
\text { lucine/g dwt) }\end{array}$ & $\begin{array}{l}\text { Peroxidase (O.D./g fwt } \\
\text { after } 2 \text { minutes) }\end{array}$ \\
\hline \multicolumn{7}{|c|}{$\overline{A-p l a n t i n g ~ d a t e}$} \\
\hline 8 April & 1.59 & 1.60 & 0.935 & 0.951 & 242.66 & 0.187 \\
\hline 8 May & 1.27 & 1.31 & 0.847 & 0.865 & 264.68 & 0.193 \\
\hline 8 June & 1.21 & 1.23 & 0.817 & 0.826 & 286.46 & 0.201 \\
\hline LSD 0.05 & 0.02 & 0.01 & 0.010 & 0.001 & 5.33 & 0.003 \\
\hline \multicolumn{7}{|c|}{$B$-Potasin- $P$ rate } \\
\hline $2.5 \mathrm{~cm}^{3} / 1$ & 1.22 & 1.23 & 0.862 & 0.868 & 269.20 & 0.196 \\
\hline $5.0 \mathrm{~cm}^{3} / 1$ & 1.62 & 1.64 & 0.875 & 0.891 & 254.62 & 0.189 \\
\hline $7.5 \mathrm{~cm}^{3} / 1$ & 1.24 & 1.27 & 0.862 & 0.882 & 269.20 & 0.196 \\
\hline LSD 0.05 & 0.03 & 0.01 & 0.002 & 0.001 & 1.33 & 0.003 \\
\hline \multicolumn{7}{|c|}{ C-Lithovit rate } \\
\hline without & 1.23 & 1.24 & 0.842 & 0.859 & 279.30 & 0.200 \\
\hline $2.5 \mathrm{~g} / 1$ & 1.30 & 1.32 & 0.851 & 0.868 & 271.12 & 0.196 \\
\hline $5.0 \mathrm{~g} / 1$ & 1.39 & 1.42 & 0.879 & 0.891 & 260.57 & 0.192 \\
\hline $7.5 \mathrm{~g} / 1$ & 1.51 & 1.54 & 0.894 & 0.904 & 246.38 & 0.186 \\
\hline LSD 0.05 & 0.02 & 0.01 & 0.003 & 0.002 & 1.27 & 0.001 \\
\hline \multicolumn{7}{|l|}{ Interactions } \\
\hline$A \times B$ & $* *$ & $* *$ & $* *$ & $* *$ & $* *$ & $* *$ \\
\hline $\mathrm{A} X \mathrm{C}$ & $* *$ & $* *$ & $* *$ & $*$ & $* *$ & $* *$ \\
\hline B X C & $* *$ & $* *$ & $* *$ & $* *$ & $* *$ & $* *$ \\
\hline $\mathrm{A} X \mathrm{~B} \times \mathrm{C}$ & $* *$ & $* *$ & $* *$ & $*$ & $* *$ & $* *$ \\
\hline
\end{tabular}

\section{4-Effect of the interactions:}

The first order interactions gave significant effects on traits under study and since the second order interaction effect on these traits was significant we will discuss the second order interaction effect only.

The second order interaction had a significant effect on all studied chemical composition of leaves (Tables 6-7-8). Cotton plants sown on 8 April and sprayed with $5 \mathrm{~cm}^{3}$ Potasin-P $/ 1$ and $7.5 \mathrm{~g}$ Lithovit/1 recorded the highest values of $\mathrm{N}, \mathrm{P}, \mathrm{K}$, chlorophyll $\mathrm{a}, \mathrm{b}$, total chlorophyll, carotenoids and total carbohydrates content in leaves. In the contrary, this interaction recorded the lowest values of leaves proline content and peroxidase activity which induced favorable plant conditions and reflect on reduce environmental stress effect.

It can be concluded that the mentioned interaction was the recommended treatment for optimum chemical composition of cotton leaves under experimental conditions. In this regard, Ozbun et al. (1965 a, b) reported that potassium deficiency decreases photosynthesis through a reduction in both leaf area and in net $\mathrm{CO}_{2}$ fixation. Reddy and Zhao (2005) reported that elevated atmospheric $\left[\mathrm{CO}_{2}\right]$ increased not only the amount of $\mathrm{K}$ nutrient required but also the sensitivity of response to leaf $\mathrm{K}$ concentration.

\begin{tabular}{|c|c|c|c|c|c|c|c|c|c|}
\hline \multirow{2}{*}{$\begin{array}{l}\text { Planting } \\
\text { date }\end{array}$} & \multirow{2}{*}{$\begin{array}{c}\text { Potasin- } \\
\mathbf{P} \\
(\mathrm{cm} 3 / \mathrm{l})\end{array}$} & \multicolumn{4}{|c|}{$\begin{array}{c}2014 \text { season } \\
\text { Lithovit rate }(\mathrm{g} / \mathrm{l})\end{array}$} & \multicolumn{4}{|c|}{$\begin{array}{c}2015 \text { season } \\
\text { Lithovit rate }(\mathrm{g} / \mathrm{l})\end{array}$} \\
\hline & & $\mathbf{0}$ & \multicolumn{6}{|c|}{ Leaves nitrogen content (\%) } & 7.5 \\
\hline & 2.5 & 3.32 & 3.40 & 3.42 & 3.46 & 3.35 & 3.43 & 3.46 & 3.47 \\
\hline \multirow[t]{3}{*}{8 April } & 5.0 & 3.36 & 3.56 & 3.46 & 3.51 & 3.39 & 3.54 & 3.51 & 3.54 \\
\hline & 7.5 & 3.33 & 3.38 & 3.42 & 3.45 & 3.34 & 3.42 & 3.47 & 3.49 \\
\hline & 2.5 & 3.30 & 3.32 & 3.39 & 3.42 & 3.29 & 3.35 & 3.43 & 3.45 \\
\hline 8 & 5.0 & 3.31 & 3.36 & 3.41 & 3.47 & 3.33 & 3.38 & 3.45 & 3.50 \\
\hline \multirow[t]{2}{*}{ May } & 7.5 & 3.29 & 3.31 & 3.38 & 3.41 & 3.30 & 3.33 & 3.41 & 3.44 \\
\hline & 2.5 & 3.16 & 3.21 & 3.21 & 3.31 & 3.15 & 3.22 & 3.23 & 3.35 \\
\hline 8 June & $\begin{array}{l}5.0 \\
7.5\end{array}$ & $\begin{array}{l}3.20 \\
3.18\end{array}$ & $\begin{array}{l}3.23 \\
3.20\end{array}$ & $\begin{array}{l}3.26 \\
3.24\end{array}$ & $\begin{array}{l}3.35 \\
3.33\end{array}$ & $\begin{array}{l}3.21 \\
3.17\end{array}$ & $\begin{array}{l}3.25 \\
3.23\end{array}$ & $\begin{array}{l}3.29 \\
3.27\end{array}$ & $\begin{array}{l}3.39 \\
3.37\end{array}$ \\
\hline LSD 0.05 & & & & & & & & & \\
\hline $\begin{array}{l}\text { Planting } \\
\text { date }\end{array}$ & $\begin{array}{l}\text { Potasin- } \\
\text { P- } \\
(\mathrm{cm} 3 / 1)\end{array}$ & \multicolumn{8}{|c|}{ Leaves phosphorus content (\%) } \\
\hline \multirow{4}{*}{8 April } & 2.5 & 0.43 & 0.49 & 0.53 & 0.56 & 0.45 & 0.48 & 0.55 & 0.58 \\
\hline & 5.0 & 0.43 & 0.48 & 0.55 & 0.56 & 0.46 & 0.51 & 0.58 & 0.59 \\
\hline & 7.5 & 0.47 & 0.51 & 0.56 & 0.59 & 0.47 & 0.53 & 0.59 & 0.61 \\
\hline & 2.5 & 0.37 & 0.42 & 0.47 & 0.51 & 0.39 & 0.43 & 0.47 & 0.49 \\
\hline 8 & 5.0 & 0.37 & 0.41 & 0.48 & 0.51 & 0.41 & 0.45 & 0.49 & 0.52 \\
\hline \multirow[t]{2}{*}{ May } & 7.5 & 0.40 & 0.44 & 0.50 & 0.53 & 0.42 & 0.46 & 0.51 & 0.53 \\
\hline & 2.5 & 0.29 & 0.30 & 0.33 & 0.35 & 0.28 & 0.31 & 0.32 & 0.35 \\
\hline \multirow[t]{2}{*}{8 June } & 5.0 & 0.30 & 0.33 & 0.33 & 0.35 & 0.30 & 0.33 & 0.35 & 0.36 \\
\hline & 7.5 & 0.31 & 0.34 & 0.36 & 0.39 & 0.32 & 0.35 & 0.36 & 0.38 \\
\hline LSD 0.05 & & \multicolumn{4}{|c|}{0.01} & \multicolumn{4}{|c|}{0.02} \\
\hline \multirow{2}{*}{$\begin{array}{l}\text { Planting } \\
\text { date }\end{array}$} & Potasin-P & \multicolumn{8}{|c|}{ Leaves potassium content (\%) } \\
\hline & 2.5 & 3.38 & 3.42 & 3.43 & 3.50 & 3.49 & 3.54 & 3.56 & 3.61 \\
\hline \multirow[t]{3}{*}{8 April } & 5.0 & 3.42 & 3.42 & 3.52 & 3.57 & 3.58 & 3.60 & 3.63 & 3.74 \\
\hline & 7.5 & 3.42 & 3.45 & 3.55 & 3.58 & 3.59 & 3.62 & 3.68 & 3.79 \\
\hline & 2.5 & 3.22 & 3.28 & 3.32 & 3.39 & 3.43 & 3.49 & 3.53 & 3.56 \\
\hline 8 & 5.0 & 3.26 & 3.31 & 3.34 & 3.42 & 3.48 & 3.57 & 3.62 & 3.68 \\
\hline \multirow[t]{2}{*}{ May } & 7.5 & 3.29 & 3.33 & 3.39 & 3.43 & 3.51 & 3.59 & 3.67 & 3.71 \\
\hline & 2.5 & 3.10 & 3.17 & 3.23 & 3.23 & 3.17 & 3.19 & 3.25 & 3.28 \\
\hline \multirow[t]{2}{*}{8 June } & 5.0 & 3.15 & 3.19 & 3.24 & 3.26 & 3.20 & 3.23 & 3.27 & 3.31 \\
\hline & 7.5 & 3.18 & 3.22 & 3.24 & 3.29 & 3.24 & 3.25 & 3.31 & 3.38 \\
\hline LSD 0.05 & & \multicolumn{4}{|c|}{0.02} & \multicolumn{4}{|c|}{0.02} \\
\hline
\end{tabular}


Attia, A. N. E. et al.

Table. 7. Means of leaves chlorophyll a, chlorophyll $b$ and total chlorophyll content as affected by the second order interaction in 2014 and 2015 seasons

\begin{tabular}{|c|c|c|c|c|c|c|c|c|c|}
\hline \multirow[t]{3}{*}{ Planting date } & \multirow{3}{*}{$\begin{array}{l}\text { Potasin-P } \\
\qquad\left(\mathrm{cm}^{3} / \mathbf{l}\right)\end{array}$} & \multicolumn{4}{|c|}{$\begin{array}{c}2014 \text { season } \\
\text { Lithovit rate }(\mathrm{g} / \mathrm{l})\end{array}$} & \multicolumn{4}{|c|}{$\begin{array}{c}2015 \text { season } \\
\text { Lithovit rate }(\mathrm{g} / \mathrm{l})\end{array}$} \\
\hline & & $\mathbf{0}$ & 2.5 & 5.0 & 7.5 & $\mathbf{0}$ & 2.5 & 5.0 & 7.5 \\
\hline & & \multicolumn{8}{|c|}{ Leaves chlorophyll a content (mg/g dwt) } \\
\hline \multirow{3}{*}{8 April } & 2.5 & 3.37 & 3.49 & 3.67 & 3.81 & 3.38 & 3.59 & 3.70 & 3.85 \\
\hline & 5.0 & 3.73 & 3.75 & 3.89 & 4.02 & 4.03 & 4.05 & 4.29 & 4.39 \\
\hline & 7.5 & 3.30 & 3.43 & 3.62 & 3.80 & 4.00 & 4.03 & 4.24 & 4.33 \\
\hline \multirow{3}{*}{8 May } & 2.5 & 3.19 & 3.20 & 3.39 & 3.64 & 3.21 & 3.24 & 3.49 & 3.71 \\
\hline & 5.0 & 3.49 & 3.62 & 3.76 & 3.84 & 3.64 & 3.71 & 3.87 & 3.99 \\
\hline & 7.5 & 3.18 & 3.24 & 3.48 & 3.61 & 3.60 & 3.68 & 3.83 & 3.87 \\
\hline \multirow{3}{*}{8 June } & 2.5 & 2.95 & 3.06 & 3.20 & 3.31 & 3.03 & 3.10 & 3.29 & 3.43 \\
\hline & 5.0 & 3.22 & 3.30 & 3.39 & 3.49 & 3.43 & 3.61 & 3.70 & 3.78 \\
\hline & 7.5 & 2.88 & 3.06 & 3.20 & 3.32 & 3.31 & 3.39 & 3.47 & 3.59 \\
\hline \multirow{3}{*}{$\begin{array}{l}\text { LSD } 0.05 \\
\text { Planting date }\end{array}$} & & \multirow{2}{*}{\multicolumn{8}{|c|}{$\begin{array}{l}0.05 \\
\text { content }\end{array}$}} \\
\hline & Potasin--P-P $\left(\mathrm{cm}^{3} / 1\right)$ & & & & & & & & \\
\hline & 2.5 & 1.39 & 1.45 & 1.53 & 1.64 & 1.37 & 1.45 & 1.55 & 1.72 \\
\hline \multirow[t]{3}{*}{8 April } & 5.0 & 1.98 & 2.04 & 2.11 & 2.16 & 2.01 & 2.11 & 2.16 & 2.22 \\
\hline & 7.5 & 1.36 & 1.48 & 1.51 & 1.63 & 1.41 & 1.51 & 1.72 & 1.92 \\
\hline & 2.5 & 1.22 & 1.23 & 1.29 & 1.47 & 1.27 & 1.31 & 1.38 & 1.37 \\
\hline \multirow{3}{*}{8 May } & 5.0 & 1.86 & 1.89 & 1.95 & 1.98 & 1.89 & 1.98 & 2.07 & 2.03 \\
\hline & 7.5 & 1.23 & 1.22 & 1.34 & 1.38 & 1.69 & 1.83 & 1.91 & 1.86 \\
\hline & 2.5 & 1.14 & 1.24 & 1.29 & 1.37 & 1.33 & 1.34 & 1.39 & 1.53 \\
\hline \multirow[t]{2}{*}{8 June } & 5.0 & 1.69 & 1.84 & 1.81 & 1.87 & 1.95 & 1.99 & 2.12 & 2.13 \\
\hline & 7.5 & 1.14 & 1.29 & 1.31 & 1.37 & 1.42 & 1.49 & 1.55 & 1.73 \\
\hline LSD 0.05 & & \multicolumn{4}{|c|}{0.05} & \multicolumn{4}{|c|}{0.03} \\
\hline \multirow[t]{2}{*}{ Planting date } & Potasin--p-P $\left(\mathrm{cm}^{3} / 1\right)$ & \multicolumn{8}{|c|}{ Leaves total chlorophyll content (mg/g dwt) } \\
\hline & 2.5 & 4.76 & 4.94 & 5.20 & 5.45 & 4.75 & 5.04 & 5.25 & 5.57 \\
\hline \multirow[t]{3}{*}{8 April } & 5.0 & 5.71 & 5.79 & 6.00 & 6.18 & 6.04 & 6.16 & 6.45 & 6.61 \\
\hline & 7.5 & 4.66 & 4.91 & 5.13 & 5.45 & 5.41 & 5.54 & 5.96 & 6.25 \\
\hline & 2.5 & 4.41 & 4.43 & 4.68 & 5.11 & 4.48 & 4.55 & 4.87 & 5.08 \\
\hline \multirow{3}{*}{8 May } & 5.0 & 5.35 & 5.51 & 5.71 & 5.82 & 5.53 & 5.69 & 5.94 & 6.02 \\
\hline & 7.5 & 4.41 & 4.46 & 4.82 & 4.99 & 5.29 & 5.51 & 5.74 & 5.73 \\
\hline & 2.5 & 4.09 & 4.30 & 4.49 & 4.68 & 4.36 & 4.44 & 4.68 & 4.96 \\
\hline \multirow[t]{2}{*}{8 June } & 5.0 & 4.91 & 5.14 & 5.20 & 5.36 & 5.38 & 5.60 & 5.82 & 5.91 \\
\hline & 7.5 & 4.02 & 4.35 & 4.51 & 4.69 & 4.73 & 4.88 & 5.02 & 5.32 \\
\hline LSD 0.05 & & \multicolumn{4}{|c|}{0.09} & \multicolumn{4}{|c|}{0.09} \\
\hline
\end{tabular}

Table. 8. Means of leaves carotenoids and carbohydrates content (mg/g dwt) in 2014 and 2015 seasons, and leaves proline concentration and leaves peroxidase activity in 2014 season as affected by the second order interaction.

\begin{tabular}{|c|c|c|c|c|c|c|c|c|c|}
\hline \multirow[t]{3}{*}{$\begin{array}{c}\text { Planting } \\
\text { date }\end{array}$} & \multirow[t]{3}{*}{$\begin{array}{l}\text { Potasin--p-P } \\
\quad\left(\mathrm{cm}^{3} / \mathbf{l}\right)\end{array}$} & \multicolumn{4}{|c|}{$\begin{array}{c}2014 \text { season } \\
\text { Lithovit rate }(\mathrm{g} / \mathrm{l})\end{array}$} & \multicolumn{4}{|c|}{$\begin{array}{c}2015 \text { season } \\
\text { Lithovit rate }(\mathrm{g} / \mathrm{l})\end{array}$} \\
\hline & & $\mathbf{0}$ & 2.5 & 5.0 & 7.5 & $\mathbf{0}$ & 2.5 & 5.0 & 7.5 \\
\hline & & \multicolumn{8}{|c|}{ Leaves carotenoids content (mg/g dwt) } \\
\hline \multirow{3}{*}{8 April } & 2.5 & 1.25 & 1.35 & 1.42 & 1.47 & 1.23 & 1.36 & 1.39 & 1.50 \\
\hline & 5.0 & 1.87 & 1.93 & 2.05 & 2.06 & 1.91 & 1.98 & 2.11 & 2.12 \\
\hline & 7.5 & 1.29 & 1.38 & 1.44 & 1.52 & 1.25 & 1.37 & 1.40 & 1.53 \\
\hline \multirow{4}{*}{8 May } & 2.5 & 1.11 & 1.08 & 1.17 & 1.36 & 1.09 & 1.11 & 1.22 & 1.39 \\
\hline & 5.0 & 1.17 & 1.39 & 1.45 & 1.75 & 1.20 & 1.34 & 1.48 & 1.81 \\
\hline & 7.5 & 1.10 & 1.08 & 1.21 & 1.42 & 1.17 & 1.18 & 1.28 & 1.47 \\
\hline & 2.5 & 0.99 & 1.09 & 1.14 & 1.21 & 0.98 & 1.07 & 1.18 & 1.22 \\
\hline \multirow[t]{2}{*}{8 June } & 5.0 & 1.27 & 1.33 & 1.51 & 1.59 & 1.25 & 1.36 & 1.53 & 1.58 \\
\hline & 7.5 & 1.00 & 1.07 & 1.14 & 1.22 & 1.05 & 1.08 & 1.23 & 1.23 \\
\hline LSD 0.05 & & \multicolumn{4}{|c|}{0.07} & \multicolumn{4}{|c|}{0.04} \\
\hline \multirow[t]{3}{*}{ Planting date } & Potasin--p-P $\left(\mathrm{cm}^{3} / 1\right)$ & \multicolumn{8}{|c|}{ Leaves total carbohydrates contents (mg/g dwt) } \\
\hline & & \multicolumn{4}{|c|}{2014 season } & \multicolumn{4}{|c|}{2015 season } \\
\hline & 2.5 & 0.894 & 0.912 & 0.950 & 0.963 & 0.904 & 0.914 & 0.953 & 0.969 \\
\hline \multirow[t]{3}{*}{8 April } & 5.0 & 0.911 & 0.923 & 0.964 & 0.975 & 0.930 & 0.944 & 0.989 & 0.992 \\
\hline & 7.5 & 0.896 & 0.909 & 0.968 & 0.958 & 0.918 & 0.929 & 0.976 & 0.990 \\
\hline & 2.5 & 0.820 & 0.824 & 0.849 & 0.877 & 0.839 & 0.847 & 0.854 & 0.870 \\
\hline \multirow[t]{3}{*}{8 May } & 5.0 & 0.833 & 0.842 & 0.867 & 0.896 & 0.858 & 0.871 & 0.883 & 0.900 \\
\hline & 7.5 & 0.812 & 0.821 & 0.853 & 0.874 & 0.850 & 0.852 & 0.871 & 0.891 \\
\hline & 2.5 & 0.802 & 0.807 & 0.815 & 0.830 & 0.805 & 0.813 & 0.822 & 0.832 \\
\hline \multirow[t]{2}{*}{8 June } & 5.0 & 0.810 & 0.814 & 0.827 & 0.842 & 0.813 & 0.824 & 0.840 & 0.851 \\
\hline & 7.5 & 0.803 & 0.806 & 0.816 & 0.830 & 0.810 & 0.819 & 0.834 & 0.845 \\
\hline LSD 0.05 & & & & & & & & & \\
\hline \multirow[t]{3}{*}{ Planting date } & Potasin--p-P $\left(\mathrm{cm}^{3} / \mathrm{l}\right)$ & \multicolumn{8}{|c|}{2014 season } \\
\hline & & \multicolumn{4}{|c|}{ Proline ( $\mu \mathrm{g}$ lucine/g dwt) } & \multicolumn{4}{|c|}{ Leaves Peroxidase (O.D./g fwt after 2 minutes) } \\
\hline & 2.5 & 269.80 & 257.81 & 237.05 & 221.52 & 0.193 & 0.191 & 0.186 & 0.182 \\
\hline \multirow[t]{3}{*}{8 April } & 5.0 & 250.90 & 239.58 & 228.33 & 207.28 & 0.188 & 0.186 & 0.185 & 0.178 \\
\hline & 7.5 & 282.62 & 257.02 & 237.02 & 223.02 & 0.196 & 0.192 & 0.185 & 0.182 \\
\hline & 2.5 & 283.04 & 277.80 & 265.23 & 259.21 & 0.203 & 0.198 & 0.193 & 0.190 \\
\hline \multirow[t]{3}{*}{8 May } & 5.0 & 262.15 & 254.49 & 248.69 & 243.92 & 0.196 & 0.191 & 0.188 & 0.181 \\
\hline & 7.5 & 279.32 & 279.11 & 265.50 & 257.66 & 0.202 & 0.198 & 0.193 & 0.189 \\
\hline & 2.5 & 303.54 & 294.97 & 289.86 & 270.58 & 0.213 & 0.209 & 0.202 & 0.194 \\
\hline \multirow[t]{2}{*}{8 June } & 5.0 & 291.14 & 286.40 & 281.94 & 260.67 & 0.199 & 0.196 & 0.194 & 0.189 \\
\hline & 7.5 & 301.17 & 292.89 & 291.54 & 272.84 & \multirow{2}{*}{\multicolumn{3}{|c|}{$0.2082^{0.202}$}} & 0.194 \\
\hline LSD 0.05 & & & & & & & & & \\
\hline
\end{tabular}


They concluded that elevated atmospheric $\left[\mathrm{CO}_{2}\right]$ stimulated cotton plant growth and biomass production through increases in both leaf area and leaf net photosynthesis, but didn't affect either leaf chlorophyll or $\mathrm{K}$ concentrations.

Plants grown under elevated $\mathrm{CO}_{2}$ conditions required greater amounts of $\mathrm{K}$ and the plants were more sensitive to $\mathrm{K}$ deficiency compared to plants grown under ambient $\left[\mathrm{CO}_{2}\right]$. Reddy and Zhao (2005) reported no interaction effect of $\mathrm{CO}_{2} \times \mathrm{K}$ on chlorophyll was found. Averaged across $\mathrm{CO}_{2}$ treatments, the 40 and 20 $\% \mathrm{~K}$ treated plant had comparable chlorophyll with those of the control. However, plants receiving 5 and 0 $\% \mathrm{~K}$ had 12 and $38 \%$ lower chlorophyll content than the control, respectively.

\section{REFERENCES}

A.O.A.C. (1995): Association of Official Agriculture Chemists. Official Methods of Analysis. $16^{\text {th }} \mathrm{Ed}$. A.O.A.C. Virginia, D.C., USA.

Ainsworth, E. A. (2008): Rice production in a changing climate: a meta-analysis of responses to elevated carbon dioxide and elevated ozone concentration. Global Change Biology 14, 16421650 (2008).

Ali, A.A.E.F. (2012): Effect of some Agricultural practices and temperature on Egyptian cotton productivity. M.Sc. Thesis, Fac. of Agric., Assiut, univ.

Al-Khatib, K. and G. M. Paulsen (1984): Mode of high temperature injury to wheat during grain development. Physiol. Plant. 61, 363-368.

Ashfaq, A.; N. Hussain and M. Athar (2015): Role of potassium fertilizers in plant growth, crop yield and quality fiber production of cotton - An overview FUUAST J. Biol., 5 (1): 27 - 35.

Bates, L. S.; R. P. Waldem and I. D. Teare (1973): Rapid determination of free proline under water stress studies Plant and Soil, 39: 205 - 207.

Bednarz, C. W. and M. W. Van Iersal (2001): Temperature response of whole-plant $\mathrm{CO}_{2}$ exchange rate of four Upland cotton cultivars differing in leaf shape and leaf pubescence. Commun. Soil Sci. Plant Anal. 32, 2485-2501.

Burke, J. J.; J. R. Mohan and J. L. Hatfield (1988): Crop specific thermal kinetic windows in relation to wheat and cotton biomass production. Agron. J. 80, 553-556.

Cakmak, I.; C. Hengeler and H. Marschner (1994): Partitioning of shoot and root dry weight and carbohydratess in bean plants suffering from phosphorus, potassium and magnesium deficiency. J., Exp. Bot., 45: 1245-1250.

Curie, C. and J. F. Briat (2003): Iron transport and signaling in plants. Annu Rev Plant Biol., 54: $183-206$.

Dong, H.; W. Tang; Li. Zhenhual and D. Zhang (2004): On potassium deficiency in cotton disorder, cause and tissue diagnosis. Agric. Conspectus Scientificus, 69 (2-3): $77-85$.
Dordas, C. (2009): Foliar application of Manganese increases seed yield and improves seed quality of cotton grown on calcareous soils. J. Plant Nutrition, 32: 160-176.

El - Ashmouny, A. A. M. (2014): Effect of some bioregulators on cotton yield grown under different planting dates and irrigation intervals. Ph. D. Thesis, Fac. of Agric., Minufiya Univ.

El-Shazly W. M. O.; K. A. Zaiadah and M. F. El-Masri (1998): Response of extra-long staple cotton cultivar, Giza 70 to a bioregulator PGR-IV rate and time of its application under three planting dates. J. Agric. Sci. Mansoura Univ., 23(2): 603631.

Fehrman, H. and A. E. Dimond (1967): Peroxidase activity and phytophthora resistance in different organs of the potato. Plant Pathology., 57: 69-72.

Harding, S. A.; J. A. Gurkema and G. M. Paulsen (1990): Photosynthesis decline from high temperature stress during maturation of wheat. I. Interaction with senescence process. Plant Physiol., 92: 648-653.

Hull, R. J. (2002): Copper management demands attention. Plant Nutrition, July 2002.

Jackson, M. L. (1973). Soil Chemical Analysis. Prentice Hall of Indian Private Limited, New Delhi.

Krieg, D. R. (1986): Feedback control and stress effects on photosynthesis. In "Proceeding of the Beltwide Cotton Conferences," pp. 227-243. National Cotton Council of America, Memphis, TN.

Kumar, P. (2011): Nanotechnology in agriculture. Financing Agriculture. 43 (10).

Le Clerg, E. L.; W. H. Leonard, and A. G. Clark (1966): Field Plot Technique. Burgess Pub. Co. Minneapolis, U.S.A.

Lohry, R. (2007): Micronutrients: functions, sources and application methods. Indiana CCA Conf. Proceeding.

Oosterhuis, D. M. (1999): Yield response to environmental extremes in cotton. In "Proceeding of the 1999 Cotton Research Meeting', (C. P. Dugger and D. A. Richter, Eds.), pp. 30-38. National Cotton Council of America, Memphis, TN.

Ozbun, J. I.; R. J. Volk and W. A. Jakson (1965 a): Effects of potassium deficiency on photosynthesis, respiration and the utilization of photosynthetic reluctant by mature bean leaves. Crop Sci., 5: $69-75$.

Ozbun, J. I.; R. J. Volk and W. A. Jakson (1965 b): Effects of potassium deficiency on photosynthesis, respiration and the utilization of photosynthetic reluctant by mature bean leaves. Crop Sci. 5: 497 - 500.

Perry, S. W. and D. R. Krieg (1981): Gross net photosynthesis ratios of cotton as affected by environment and genotype. Proceedings of the Beltwide Cotton Production Research Conference 1981, 51. 
PinterJr,P. J.; S. B. Idso; D. L. Hendrix; R. R. Rokey; R.S. Rauschkolb; J. R. Mauney; B, A. Kimball; G,R. Hendrey; K.F. Lewin and J. Nagy (1994): Effect of free-air $\mathrm{CO} 2$ enrichment on the chlorophyll content of cotton leaves. Agric. and Forest Meteorology, 70 (1-4): 163-169.

Reddy, K. R. and D. Zhao (2005): Interactive effects of elevated $\mathrm{CO}_{2}$ and potassium deficiency on photosynthesis, growth, and biomass partitioning of cotton. Field Crops Res., 94: 201 - 213.

Reddy, K. R.; H. F. Hodges and J. M. McKinion (1995): Cotton crop responses to a changing environment. In "Climate Change and Agriculture: Analysis of Potential International Impacts" (C. Rosenzweig, J. T. Ritchie, J. W. Jones, G. Y. Tsuji, and P. Hilderbrand, Eds.), pp. 3-30. ASA Spec. Publ. No. 59, Madison, WI.

Ronde, J., A. Mescht and H.S.F. Steyn (2001): Proline accumulation in response to drought and heat stress in cotton. African Crop Sci. J., 8(1): 85-91.

Siddiqui, M. H.; M. H. Al - Whaibi; M. Firoz and M. Y. Al - Khaishany (2015): Role of nanoparticles in plants. Nanotechnology and plant Sci., chapter 2: $19-35$.

Singh, R. P.; P. V. V. Prasad; K. Sunita; S. N. Giri and K. R. Reddy (2007): Influence of high temperature and breeding for heat tolerance in cotton: A review. Advances in Agronomy, 93: 314-353.
Tucker, M. R. (1999): Essential plant nutrients: Their presence in North Carolina soils and role in plant nutrition.

Uchida, R. (2000): Essential nutrients for plant growth: nutrient functions and deficiency symptoms. Plant Nutrient Management in Hawaiis Soils. Approaches for tropical and Subtropical Agric., Chapter 3: 31-55.

Waller, R. A. and D. B. Duncan (1969): A bays rule for the symmetric multiple comparison problem. J. Amer. Stat. Assoc., 1485-1503.

Zembala, M.; Filek, M., Walas, S., Mrowiec, H., Kornas, A., Miszalski, Z., Hartikainen, H., (2010): Effect of selenium on macro- and microelement distribution and phys- iological parameters of rape and wheat seedlings exposed to cadmium stress. Plant and Soil, 329 (1-2), 457-468.

Zhao, D.; D. M. Oosterhuis and C. W. Bednarz (2001): Influence of potassium deficiency on photosynthesis chlorophyll content and chloroplast ultrastructure of cotton plants. Photosynthetic, 39: 103 - 109.

\section{تأثير سماد النانو (ليثوفيث) والبوتاسيوم على التركيب الكيماوى لأوراق القطن المصرى تحت مواعيد زراعة مختلفة.

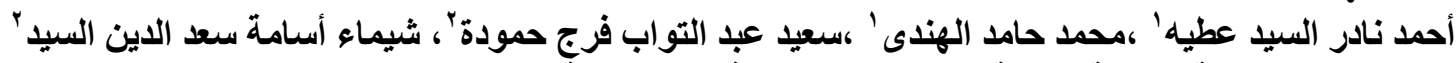

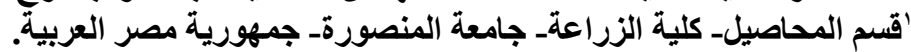

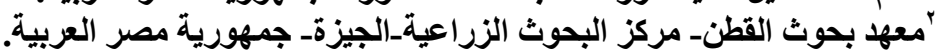

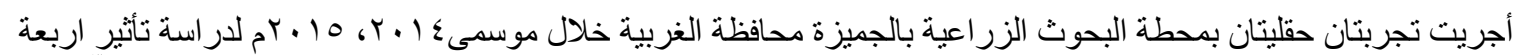

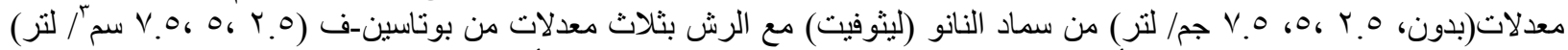

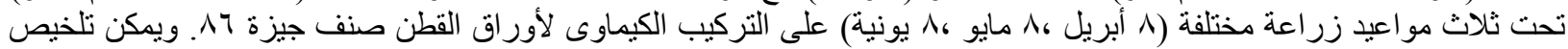

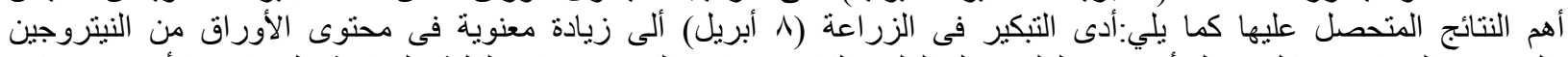

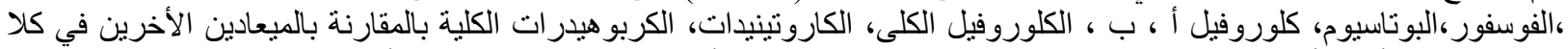

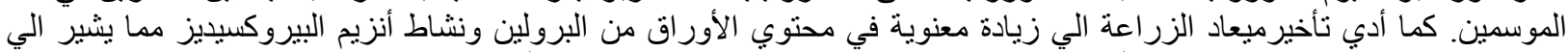

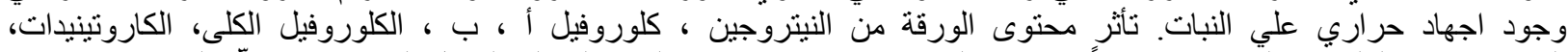

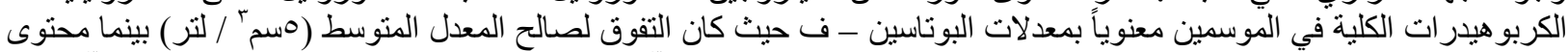

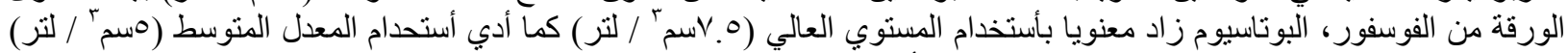

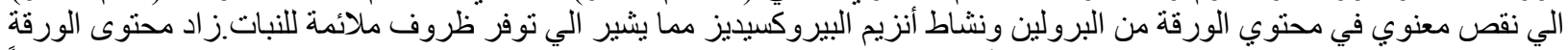

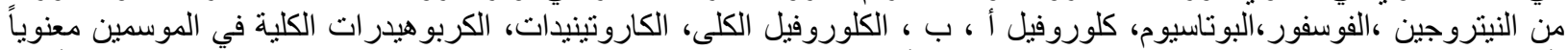

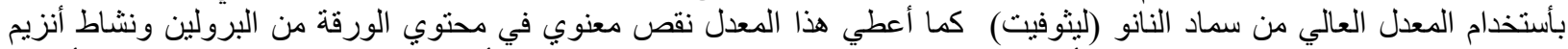

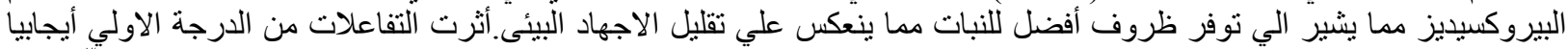

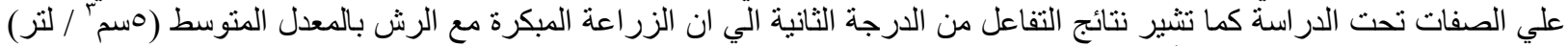

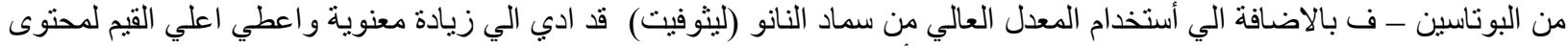

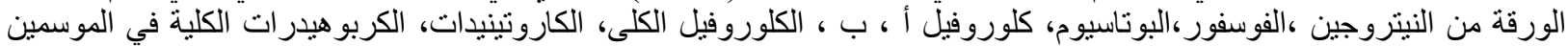

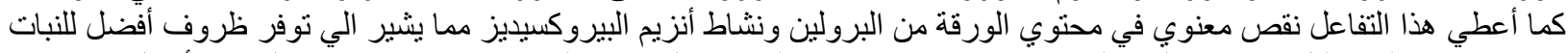

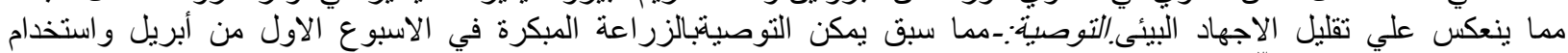

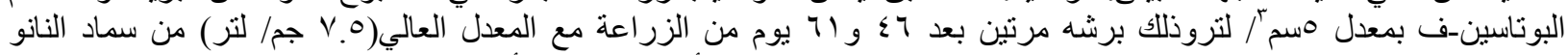

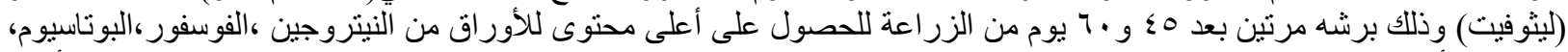

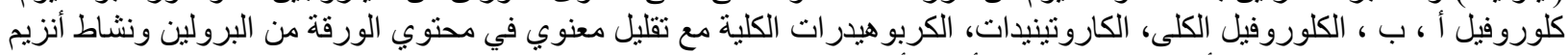

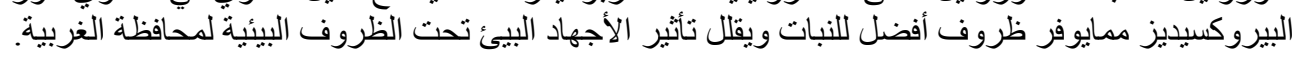

